\title{
Abnormal phenotypic features of IgM+B cell subsets in patients with chronic hepatitis $\mathrm{C}$ virus infection
}

\author{
FANYUN KONG $^{1,2}$, BO FENG $^{1}$, HENGHUI ZHANG ${ }^{1}$, \\ HUIYING RAO $^{1}$, JIANGHUA WANG ${ }^{1}, \mathrm{XU}_{\text {CONG }}{ }^{1}$ and LAI WEI ${ }^{1}$ \\ ${ }^{1}$ Beijing Key Laboratory for Hepatitis C and Immunotherapy for Liver Disease, Peking University People's Hospital, \\ Peking University Hepatology Institute, Beijing 100044; ${ }^{2}$ Department of Pathogenic Biology and Immunity, \\ Key Laboratory of Immunity and Metabolism, Xuzhou Medical University, Xuzhou, Jiangsu 221004, P.R. China
}

Received September 24, 2015; Accepted April 24, 2017

DOI: $10.3892 / \mathrm{etm} .2017 .4682$

\begin{abstract}
Hepatitis C virus (HCV) infection is associated with B cell abnormality; however the phenotypic profiles of immunoglobulin $(\mathrm{Ig}) \mathrm{M}+\mathrm{B}$ cell subsets in patients with $\mathrm{HCV}$ infection remain unclear. In the current study, the effect of $\mathrm{HCV}$ infection on IgM+B cell subsets was evaluated. The percentages, as well as the differentiation and activation features of peripheral IgM+B naive subsets [cluster of differentiation (CD)27-IgM+B cells] and IgM+B memory subsets $(\mathrm{CD} 27+\operatorname{IgM}+\mathrm{B}$ cells) were assessed using flow cytometry in 27 patients with chronic hepatitis $\mathrm{C}$ (CHC) and 20 healthy controls (HCs). The frequency of CD27+IgM+B memory subsets detected in patients with $\mathrm{CHC}$ was significantly higher than that in $\mathrm{HCs}(\mathrm{P}<0.05)$. Although the frequency of $\mathrm{CD} 27-\operatorname{IgM}+\mathrm{B}$ naive subsets was similar in both groups, there was a significantly higher proportion of CD5+B cells detected in the CD27-IgM+B subsets of patients with $\mathrm{CHC}$ compared with $\mathrm{HCs}(\mathrm{P}<0.05)$. Among $\mathrm{CD} 27-\mathrm{IgM}+\mathrm{B}$ subsets, abnormal differentiation was associated with $\mathrm{HCV}$ infection, with significantly increased percentages of $\operatorname{IgD}+\mathrm{B}$ cells and CD38+B cells in patients with CHC compared with $\mathrm{HCs}$ $(\mathrm{P}<0.05)$. In $\mathrm{CD} 27+\operatorname{IgM}+\mathrm{B}$ memory subsets, the abnormality of cell differentiation was associated with a significantly increased percentage of $\mathrm{CD} 38+\mathrm{B}$ cells in patients with $\mathrm{CHC}$ compared with $\mathrm{HCs}(\mathrm{P}<0.05)$. In addition, the percentage of activated $\mathrm{CD} 27+\operatorname{IgM}+\mathrm{B}$ subsets in patients with $\mathrm{CHC}$ were significantly higher than those observed in $\mathrm{HCs}(\mathrm{P}<0.05)$. The number of CD27-IgD+IgM+B, CD27-CD38+IgM+B and $\mathrm{CD} 27+\mathrm{CD} 38+\operatorname{IgM}+\mathrm{B}$ cells were negatively correlated with
\end{abstract}

Correspondence to: Dr Lai Wei, Beijing Key Laboratory for Hepatitis $\mathrm{C}$ and Immunotherapy for Liver Disease, Peking University People's Hospital, Peking University Hepatology Institute, 11 Xizhimen South Street, Beijing 100044, P.R. China

E-mail: weilai@pkuph.edu.cn

Key words: hepatitis $\mathrm{C}$, immunoglobulin $\mathrm{M}+\mathrm{B}$ cells, activation, differentiation
HCV RNA in patients with CHC. These results suggest that $\mathrm{HCV}$ infection contributes to abnormalities in the percentage, differentiation and activation of IgM+B cell subsets and may disrupt the immune response mediated by IgM+B cells.

\section{Introduction}

Chronic hepatitis $\mathrm{C}$ virus (HCV) infection may cause chronic hepatitis and is associated with liver cirrhosis and hepatocellular carcinoma (1). Although HCV infection primarily affects the liver, the virus is capable of evading the immune response of the host by suppressing specific $\mathrm{T}$ and $\mathrm{B}$ cell responses (2). Furthermore, a number of autoimmune diseases have been identified in patients with chronic hepatitis $\mathrm{C}$ (CHC) (3), indicating that $\mathrm{HCV}$ infection disrupts the normal activity of the immune system. Therefore, improving understanding regarding immune-associated abnormalities in patients with CHC may help to control HCV progression and lead to the development of more effective treatment strategies.

Normal B cell development contributes to an effective immune response to remove pathogens, whereas disturbance of $\mathrm{B}$ cell differentiation and activation leads to the disruption of $\mathrm{B}$ cell homeostasis in chronic infection and autoimmunity disease (4-6). Previous studies have demonstrated that B cell disorders mediated by $\mathrm{HCV}$ infection are not only associated with B cell subset skewing, with an increased proportion of immature B cells and a decreased proportion of memory $B$ cells (7-10), but are also associated with the increased activation of naive and memory B cells (11-13). Immunoglobulin (Ig) $\mathrm{M}+\mathrm{B}$ cells are responsible for the production of $\operatorname{IgM}$ antibodies and are involved in the pathogenesis of viral infections and autoimmunity diseases (14-16). Roughan et al (17) determined that there is a higher frequency of circulating IgM+B memory subsets in the peripheral blood of patients with $\mathrm{CHC}$; however the phenotypic features of different IgM+B cell subsets and associated risk factors in patients with $\mathrm{CHC}$ remain unknown.

The present study aimed to identify the effects of $\mathrm{HCV}$ infection on IgM+B cell subsets. The percentage, differentiation and activation status of peripheral $\mathrm{IgM}+\mathrm{B}$ cell subsets was evaluated in patients with $\mathrm{CHC}$ using flow cytometry. In addition, the association between IgM+B cell subsets and different clinical parameters was investigated in patients with CHC. 


\section{Patients and methods}

Patients and controls. The study population consisted of 27 patients with $\mathrm{CHC}$ with genotype $1 \mathrm{~b}$, including 11 male and 16 female patients (mean age 54.8 years), and 20 age- and sex-matched healthy controls (HCs; 9 male and 11 female patients; mean age 50 years). Patients with CHC were recruited in November 2013 from Guan county (China), in which the majority of patients are infected with $\mathrm{HCV}$ genotype $1 \mathrm{~b}$ (18). Inclusion criteria of patients with chronic $\mathrm{HCV}$ infection were: Positive $\mathrm{HCV}$ antibodies and $\mathrm{HCV}$ RNA levels $(>2,000 \mathrm{IU} / \mathrm{ml})$ in the past 6 months. Exclusion criteria were: Co-infection with hepatitis B virus or human immunodeficiency virus. The HCs were tested negative for HCV antibodies. In addition, liver damage induced by $\mathrm{HCV}$ infection was monitored via measuring serum alanine aminotransferase (ALT). The baseline characteristics of all study subjects are presented in Table I. The present study was approved by the Ethics Committee of Peking University People's Hospital (Beijing, China) and all participants provided written informed consent.

Clinical tests and peripheral blood mononuclear cell (PBMC) preparation. Levels of HCV antibodies, HCV RNA and HCV genotypes were determined as previously described (18). ALT was detected using a Hitachi 7600 automated biochemical analyzer (Hitachi, Ltd., Tokyo, Japan). PBMCs were isolated using density gradient centrifugation with Ficoll-Paque Plus (GE Healthcare Life Sciences, Uppsala, Sweden), as described previously (19). PBMCs were kept in liquid nitrogen until analysis.

Flow cytometric analysis. To measure the phenotypic features of peripheral $\operatorname{IgM}+\mathrm{B}$ cell subsets, $1 \times 10^{6} \mathrm{PBMCs}$ were incubated in $200 \mu \mathrm{l}$ blocking solution consisting of $2 \%$ bovine serum albumin (Genview Corp., Houston, TX, USA) in PBS for $30 \mathrm{~min}$ at room temperature to block non-specific binding. Cells were stained with different fluorescent conjugated anti-human antibodies: Peridinin chlorophyll protein (PerCP)-conjugated anti-cluster of differentiation (CD)19 antibody (catalogue no. 340421; 1:100), allophycocyanin (APC)-conjugated anti-CD5 antibody (catalogue no. 340583; 1:100), APC-conjugated anti-IgD antibody (catalogue no. 561303; 1:100), APC-conjugated anti-CD10 antibody (catalogue no. 340923; 1:100) and phycoerythrin (PE)-conjugated anti-CD21 antibody (catalogue no. 555422; 1:100) were purchased from BD Pharmingen (BD Biosciences, San Jose, CA, USA). Fluorescein isothiocyanate (FITC)-conjugated anti-CD27 antibody (catalogue no. 11-0279; 1:100), APC-conjugated anti-CD38 antibody (catalogue no. 17-0389; 1:100), APC-conjugated anti-IgM antibody (catalogue no. 17-9998; 1:100), PE-conjugated anti-IgM antibody (catalogue no. 12-9998; 1:100), PE-conjugated anti-CD86 antibody (catalogue no. 12-0869; 1:100) and PE-conjugated anti-CD95 (catalogue no. 12-0959; 1:100) antibody were purchased from eBioscience (Thermo Fisher Scientific, Inc., Waltham MA, USA). Cells were incubated with these antibodies for $20 \mathrm{~min}$ at room temperature in the dark.

In addition, PBMCs were incubated with isotype-matched control antibodies listed below for $20 \mathrm{~min}$ at room temperature
Table I. Baseline characteristics of subjects.

\begin{tabular}{lccc}
\hline Parameters & CHC & HC & P-values \\
\hline Subjects (n) & 27 & 20 & N/A \\
Age (years) & $54.8 \pm 10.4$ & $50.0 \pm 5.7$ & $0.06^{\mathrm{a}}$ \\
Sex, male/female & $11 / 16$ & $9 / 11$ & 0.77 \\
ALT & $45.9 \pm 36.6$ & $26.7 \pm 15.4$ & $0.03^{\mathrm{a}}$ \\
Genotype (1b), n & 27 & N/A & N/A \\
HCV-RNA $\left(\log _{10} \mathrm{IU} / \mathrm{ml}\right)$ & $6.9 \pm 0.8$ & N/A & N/A \\
\hline
\end{tabular}

All data are presented as the mean \pm standard deviation, unless otherwise specified. ${ }^{\mathrm{P}} \mathrm{P}<0.05$; $\mathrm{CHC}$, chronic hepatitis $\mathrm{C}$; $\mathrm{HC}$, healthy control; $\mathrm{HCV}$, hepatitis $\mathrm{C}$ virus; ALT, alanine transaminase; N/A, not applicable.

in the dark to determine background levels of staining. PerCP Mouse IgG1 $\kappa$ Isotype Control (catalogue no. 559425; 1:100), APC Mouse IgG1, $\kappa$ Isotype Control (catalogue no. 550854; 1:100) and APC Mouse IgG2b $\kappa$ Isotype Control (catalogue no. $555745 ; 1: 100)$ were purchased from BD Biosciences. Mouse IgG1 K isotype control FITC (catalogue no. 11-4714; 1:100), Mouse IgG2b K isotype control PE (catalogue no. 12-4732; 1:100), and Mouse IgG1 K isotype control PE (catalogue no. 12-4714; 1:100) were purchased from eBioscience (Thermo Fisher Scientific, Inc.).

Following washing twice with PBS, the cells were fixed with $1 \%$ paraformaldehyde in the dark at $4^{\circ} \mathrm{C}$ for $12 \mathrm{~h}$. Then the expression of surface molecules on cells were assayed using the BD FACSCalibur (BD Biosciences) and data were analyzed using FlowJo 7.6 software (Tree Star, Inc., Ashland, OR, USA). Based on expression of CD5, B cells were divided into $\mathrm{CD} 5+\mathrm{B}$ cells (B1 cells) and CD5-B cells (B2 cells) (20). Depending on the expression of CD27, a distinct memory $\mathrm{B}$ cell marker, IgM+B cells were divided into naive subsets (CD27-IgM+B cells) and memory subsets (CD27+IgM+B cells) (17). In addition, CD21 was used to identify activated subsets (CD21-cells) and resting subsets (CD21+cells) in naïve B cells and memory B cells (7).

Statistical analysis. Data are presented as the mean \pm standard deviation. Comparisons in all experiments were performed using Student's t-test or two-sample Wilcoxon rank-sum (Mann-Whitney) tests, according to data distribution measured using a Kolmogorow-Smirnov test with SPSS 16.0 software (SPSS, Inc., Chicago, IL, USA). The linear correlation between variables was analyzed using GraphPad Prism 5 (GraphPad Software, Inc., La Jolla, CA, USA). P $<0.05$ was considered to indicate a statistically significant difference.

\section{Results}

Frequency of $C D 27+\operatorname{Ig} M+B$ memory subsets in total $B$ cells of patients with $\mathrm{CHC}$. To characterize $\operatorname{IgM}+\mathrm{B}$ cells (CD19+IgM+B cells) in patients infected with $\mathrm{HCV}$, the frequency of $\mathrm{IgM}+\mathrm{B}$ cells in patients with $\mathrm{CHC}$ and $\mathrm{HCs}$ was detected using flow cytometry (Fig. 1A). There were no significant differences between the frequency of total 
A

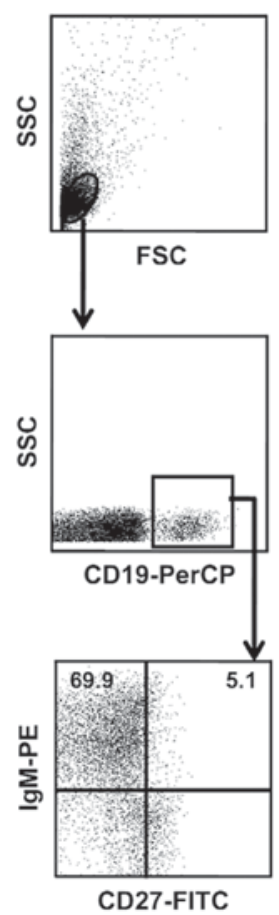

B
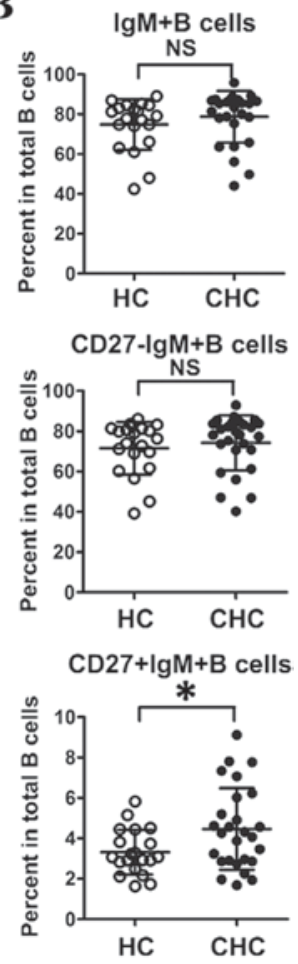

Figure 1. Frequency of $\mathrm{CD} 27+\operatorname{IgM}+\mathrm{B}$ cells in patients with $\mathrm{CHC}$ and $\mathrm{HCs}$. (A) Gating strategy for IgM+B cell subsets by flow cytometry. (B) Frequencies of $\operatorname{IgM}+\mathrm{B}, \mathrm{CD} 27-\mathrm{IgM}+\mathrm{B}$ and $\mathrm{CD} 27+\operatorname{IgM}+\mathrm{B}$ cells in total B cells. ${ }^{*} \mathrm{P}<0.05$. PerCP, peridinin chlorophyll; $\mathrm{PE}$, phycoerythrin; $\mathrm{CHC}$, chronic hepatitis $\mathrm{C}$; $\mathrm{HC}$, healthy control; NS, no significant difference; FSC, forward scatter; SSC, side scatter; Ig, immunoglobulin; FITC, Fluorescein isothiocyanate; $\mathrm{CD}$, cluster of differentiation.

IgM+B cells in patients with $\mathrm{CHC}$ and $\mathrm{HCs}$ (Fig. 1B). The percentage of IgM+B naive subsets (CD27-IgM+B cells) and IgM+B memory subsets (CD27+IgM+B cells) were further assessed in both groups (Fig. 1A). As presented in Fig. 1B, there was no significant difference between the frequency of $\mathrm{CD} 27-\mathrm{IgM}+\mathrm{B}$ cells in patients with $\mathrm{CHC}$ and $\mathrm{HCs}$. However, the frequency of $\mathrm{CD} 27+\operatorname{IgM}+\mathrm{B}$ cells was significantly higher in patients with $\mathrm{CHC}$ than in $\mathrm{HCs}(\mathrm{P}<0.05$; Fig. 1B). This suggests that infection with $\mathrm{HCV}$ may disrupt the homeostasis of $\operatorname{IgM}+\mathrm{B}$ cell subsets.

Percentage of $C D 5+B$ cells in CD27-IgM+B cells of patients with $\mathrm{CHC}$. Previous research has demonstrated that expansion of $\mathrm{CD} 5+\mathrm{B}$ cells is associated with $\mathrm{HCV}$ infection (21), whereas the association between $\mathrm{CD} 5+\mathrm{B}$ cells and $\mathrm{IgM}+\mathrm{B}$ cell subsets is unclear in patients with $\mathrm{HCV}$ infection. In the current study, the percentage of $\mathrm{CD} 5+\mathrm{B}$ cells in total $\mathrm{B}$ cells was significantly higher in patients with $\mathrm{CHC}$ compared with $\mathrm{HCs}(\mathrm{P}<0.05$; Fig. 2), which was consistent with a previous report (21). The percentage of $\mathrm{CD} 5+\mathrm{B}$ cells in IgM+B cell subsets was also measured in the current study. The results indicated that the frequency of CD5+B cells was significantly higher in CD27-IgM+B cells from patients with $\mathrm{CHC}$ compared with HCs ( $\mathrm{P}<0.05$; Fig. 2), while there was no significant difference in the frequency of $\mathrm{CD} 5+\mathrm{B}$ in $\mathrm{CD} 27+\operatorname{IgM}+\mathrm{B}$ cells between the two groups (Fig. 2). This suggests that only CD27-IgM+B cells are associated with expansion of $\mathrm{CD} 5+\mathrm{B}$ cells in $\mathrm{HCV}$ infection.

Abnormal differentiation of CD27-IgM+B and CD27+IgM+B subsets in patients with $C H C$. B cell homeostasis is primarily dependent on B cell differentiation and activation $(22,23)$. Thus, the differentiation of IgM+B cells in both IgM+B cell subsets was evaluated in the current study. IgM+B cells at the differentiation stage transition from immature $B$ cells to plasmablasts $(22,23)$. In the current study, immature B cells were CD27-CD10+B cells (Fig. 3A). The percentage of CD27-CD10+B cells in IgM+B cells was determined in both groups, and the results demonstrated that the frequency of CD27-CD10+IgM+B cells in IgM+B cells was significantly higher in patients with $\mathrm{CHC}$ compared with $\mathrm{HCs}(\mathrm{P}<0.05$; Fig. 3B). At naïve B cells differentiate into plasmablasts, $B$ cell differentiation is associated with alterations in $\operatorname{IgD}$ and CD38 expression $(22,23)$ and the current study measured the expression of IgD and CD38 in IgM+B cell subsets. As presented in Fig. 3C, a significantly higher percentage of IgD+B cells in CD27- $\operatorname{IgM}+\mathrm{B}$ cells was identified in patients with $\mathrm{CHC}$ compared with $\mathrm{HCs}(\mathrm{P}<0.05)$, whereas there were no significant differences in the frequency of $\operatorname{IgD}+\mathrm{B}$ cells in $\mathrm{CD} 27+\operatorname{IgM}+\mathrm{B}$ cells between the two groups. Furthermore, a significantly higher percentage of $\mathrm{CD} 38+\mathrm{B}$ cells was observed in $\mathrm{CD} 27-\operatorname{Ig} \mathrm{M}+\mathrm{B}$ and $\mathrm{CD} 27+\operatorname{Ig} \mathrm{M}+\mathrm{B}$ cells in patients with $\mathrm{CHC}$ compared with $\mathrm{HCs}(\mathrm{P}<0.05$; Fig. 3D). Together, these results indicate that HCV infection is associated with the abnormal differentiation of CD27-IgM+B and $\mathrm{CD} 27+\operatorname{Ig} \mathrm{M}+\mathrm{B}$ cells.

Activation of $C D 27+\operatorname{Ig} M+B$ subsets in patients with $\mathrm{CHC}$. The activation of $\operatorname{IgM}+\mathrm{B}$ subsets in both groups was investigated (Fig. 4A). As shown in Fig. 4B, compared with $\mathrm{HCs}$, the number of activated $\mathrm{CD} 27+\operatorname{IgM}+\mathrm{B}$ cells (CD27+IgM+CD21-B cells) increased significantly in patients with $\mathrm{CHC}(\mathrm{P}<0.05)$; however, there were no significant differences between the number of activated CD27-IgM+B cells (CD27-IgM+CD21-B cells) in patients with $\mathrm{CHC}$ compared with HCs (Fig. 4B).

Activated $\mathrm{B}$ cells are associated with high levels of the co-stimulatory molecules CD86 and CD95, and the abnormal expression of these molecules in B cells is associated with chronic diseases such as autoimmune hepatitis and rheumatoid arthritis $(24,25)$. Based on this, levels of CD86 and CD95 were evaluated in CD27+IgM+B cells, using mean fluorescence intensity to represent molecule expression. The results demonstrated that the expression of CD86 and CD95 in CD27+IgM+B cells was similar in patients with $\mathrm{CHC}$ and HCs (Fig. 4C and D). Taken together, these results suggest that HCV infection is associated with the activation of $\mathrm{CD} 27+\operatorname{IgM}+\mathrm{B}$ cell subsets but is not associated with the expression of CD86 and CD95 in CD27+IgM+B cells.

Correlation of HCV RNA and ALT with IgM+B cell subsets in patients with $C H C$. In order to evaluate the association between IgM+B cell subsets and clinical parameters in patients with $\mathrm{CHC}$, it was investigated whether $\operatorname{IgM}+\mathrm{B}$ subsets were correlated with HCV RNA and the liver cell damage marker ALT. As presented in Fig. 5A, the percentages of CD27-IgD+IgM+B cells $\left(\mathrm{P}<0.01, \mathrm{r}^{2}=0.49\right), \mathrm{CD} 27-\mathrm{CD} 38+\operatorname{Ig} \mathrm{M}+\mathrm{B}$ cells $\left(\mathrm{P}<0.01, \mathrm{r}^{2}=0.34\right)$ and $\mathrm{CD} 27+\mathrm{CD} 38+\operatorname{Ig} \mathrm{M}+\mathrm{B}$ cells $\left(\mathrm{P}=0.01, \mathrm{r}^{2}=0.23\right)$ were negatively correlated with viral load in patients with $\mathrm{CHC}$. 
A
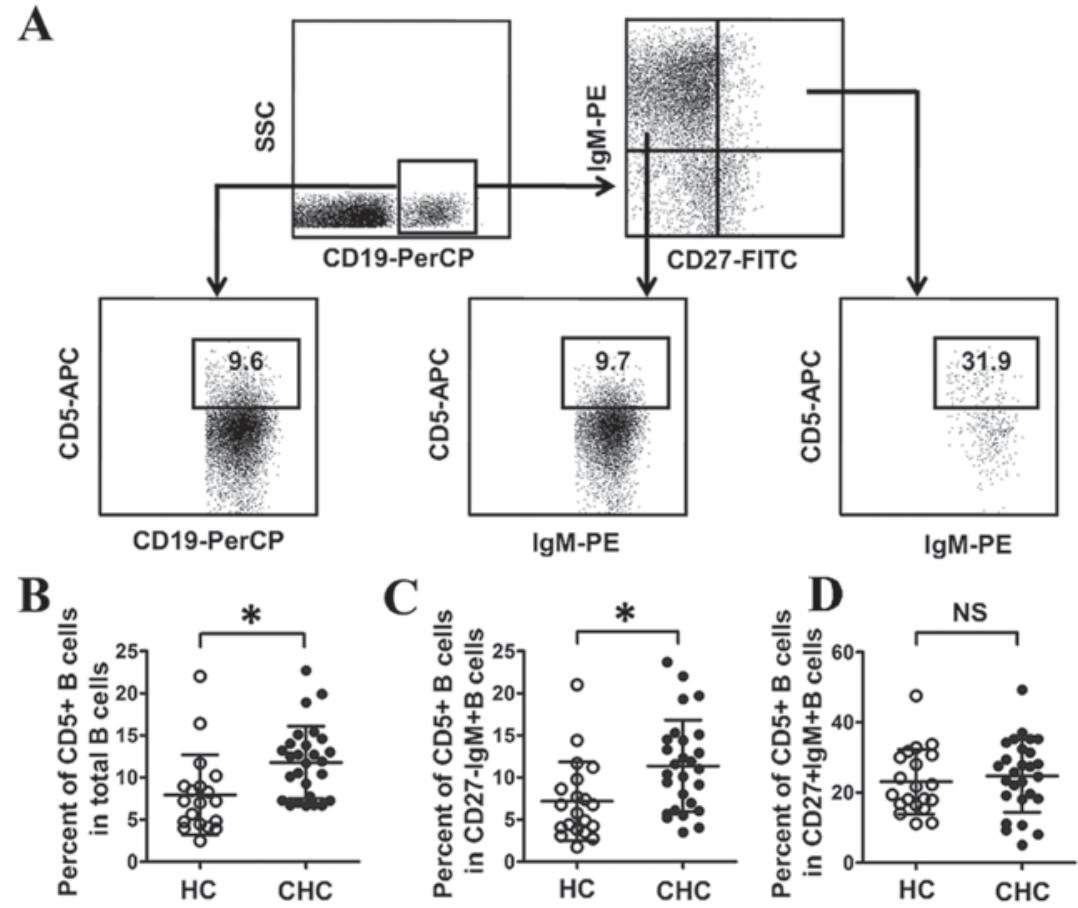

Figure 2. Frequency of CD5+B cells in patients with CHC. (A) Gating strategy for measuring the frequency of CD5+B cells in different B cell subsets by flow cytometry. (B) Frequency of CD5+B cells in total B cells. (C) Frequency of CD5+B cells in CD27-IgM+B cells. (D) Frequency of CD5+B cells in CD27+IgM+B cells. "P<0.05. CHC, chronic hepatitis C; HC, healthy control; NS, no significant difference; SSC, side scatter; PE, phycoerythrin; FITC, fluorescein isothiocyanate; PerCP, peridinin chlorophyll; APC, allophycocyanin; Ig, immunoglobulin; CD, cluster of differentiation.

A

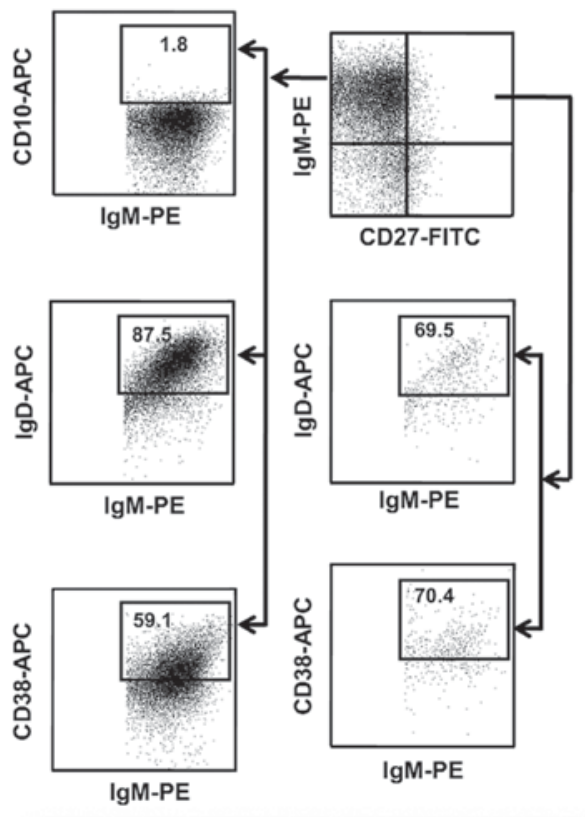

B

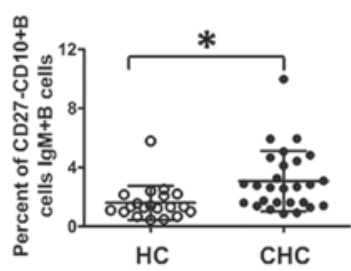

C

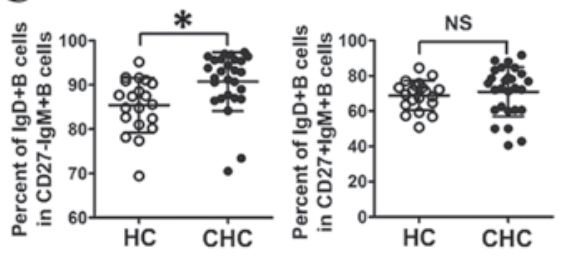

D

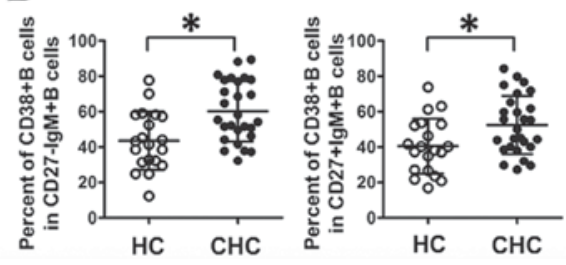

Figure 3. Abnormal differentiation of IgM+B cell subsets in patients with CHC. (A) Gating strategy for measuring the differentiation of IgM+B cell subsets by flow cytometry. (B) Frequency of CD27-CD10+B cells in IgM+B cells. (C) Frequency of IgD+B cells in IgM+B cell subsets. (D) Frequency of CD38+B cells in IgM+B cell subsets. " $\mathrm{P}<0.05$. CHC, chronic hepatitis C; HC, healthy control; NS, no significant difference; PE, phycoerythrin; PerCP, peridinin chlorophyll; Ig, immunoglobulin; CD, cluster of differentiation; APC, allophycocyanin.

However, no significant correlations between any IgM+B cell subsets and ALT were detected in patients with CHC (Fig. 5B). Thus, these data indicate that there is a HCV but not ALT is negatively correlated with the abnormal expression of certain IgM+B cell subsets.

\section{Discussion}

It has been demonstrated that abnormalities of peripheral B cell subsets are associated with $\mathrm{HCV}$ infection (7-13). However, the effect of HCV infection on the differentiation and activation of 

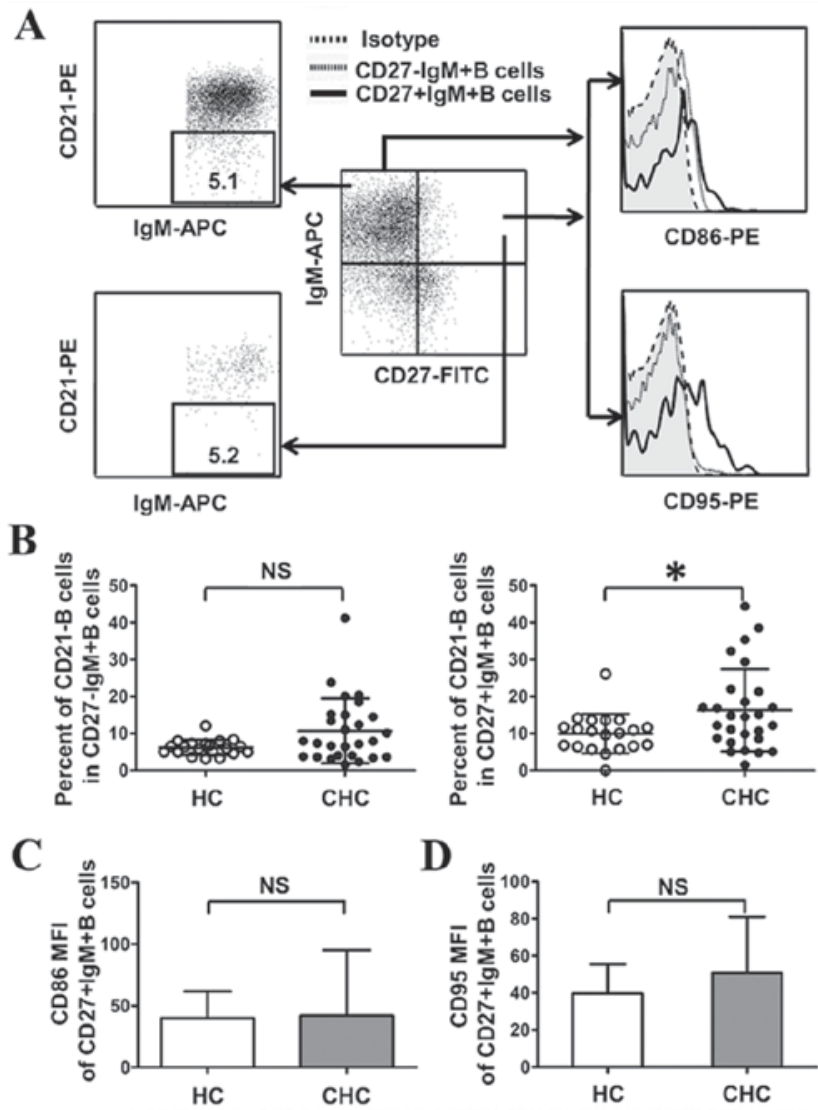

Figure 4. Activation of $\mathrm{CD} 27+\operatorname{IgM}+\mathrm{B}$ cell subsets in patients with $\mathrm{CHC}$. (A) Gating strategy to detect IgM+B cell subsets and activation markers (B) Frequencies of CD21-B cells in IgM+B subsets. (C) Expression of CD86 in $\mathrm{CD} 27+\operatorname{IgM}+\mathrm{B}$ cells. (D) Expression of CD95 in CD27+IgM+B subsets. ${ }^{*} \mathrm{P}<0.05$. CHC, chronic hepatitis C; HC, healthy control; NS, no significant difference; PE, phycoerythrin; APC, allophycocyanin; FITC, fluorescein isothiocyanate; MFI, mean fluorescence intensity; Ig, immunoglobulin; CD, cluster of differentiation.

IgM+B cell subsets has not been fully elucidated. The current study aimed to characterize $\operatorname{IgM}+\mathrm{B}$ cell subsets in patients with $\mathrm{CHC}$ and the results indicated that $\mathrm{HCV}$ infection was responsible for abnormalities in the percentage, differentiation and activation of $\operatorname{IgM}+\mathrm{B}$ cell subsets. In addition, negative correlations between viral load and $\mathrm{CD} 27-\operatorname{IgD}+\operatorname{IgM}+\mathrm{B}$ cells, CD27-CD38+IgM+B cells and CD27+CD38+IgM+B cells were detected in patients with $\mathrm{CHC}$.

Roughan et al (17) demonstrated that IgM+ memory $\mathrm{B}$ cells were expanded in patients with $\mathrm{CHC}$, and identified that the unusual polyclonal expansion of the IgM+ memory B cell subset was made up of autoreactive B cells. Consistent with a previous report (17), the present study demonstrated that an increase in $\mathrm{CD} 27+\operatorname{IgM}+\mathrm{B}$ cells was associated with $\mathrm{HCV}$ infection. The frequency of $\mathrm{CD} 27-\mathrm{IgM}+\mathrm{B}$ cells in patients with $\mathrm{CHC}$ was similar to that in HCs. However, the percentage of $\mathrm{CD} 5+\mathrm{B}$ cells, which are not only characterized by the production of low-affinity IgM that recognizes a variety of self-antigens but also serve an important role in the pathogenesis of autoimmunity disease (26), was higher in the $\mathrm{CD} 27-\mathrm{IgM}+\mathrm{B}$ cells of patients with $\mathrm{CHC}$ than in HCs. This implies that CD27-IgM+B cells may be involved in the reaction to autoantigens in patients with $\mathrm{CHC}$. Taken together, these results suggest that abnormalities of CD27-IgM+B and
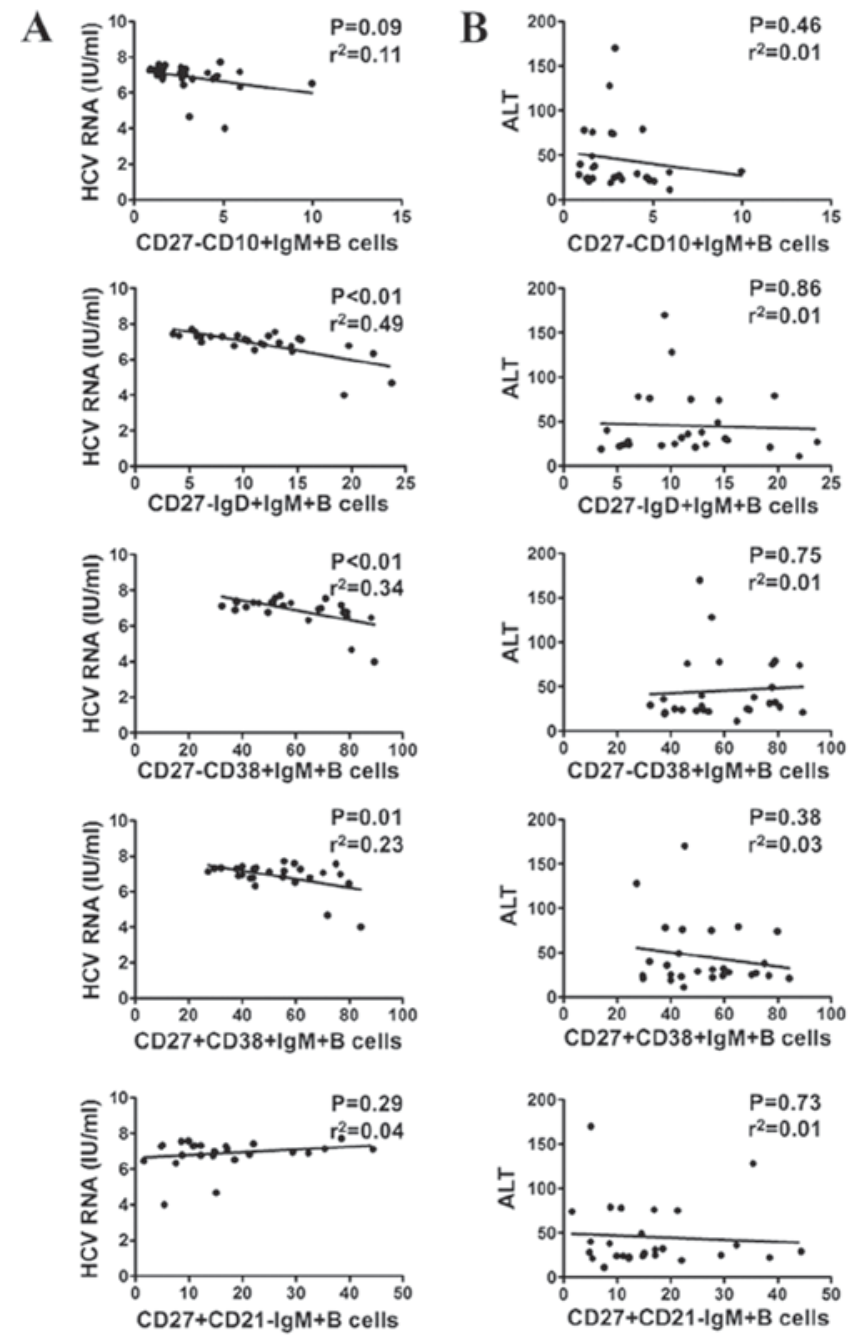

Figure 5. Correlation analysis of HCV RNA and ALT with different IgM+B cell subsets in patients with CHC. (A) Correlation of HCV RNA with CD27-CD10+IgM+B, CD27-IgD+IgM+B, CD27-CD38+IgM+B cells, $\mathrm{CD} 27+\mathrm{CD} 38+\operatorname{IgM}+\mathrm{B}$ and $\mathrm{CD} 27+\mathrm{CD} 21-\operatorname{IgM}+\mathrm{B}$ cells. (B) Correlation of ALT with CD27-CD10+IgM+B cells, CD27-IgD+IgM+B cells, CD27-CD 38+IgM+B cells, CD27+CD38+IgM+B cells, and $\mathrm{CD} 27+\mathrm{CD} 21-\mathrm{IgM}+\mathrm{B}$ cells. $\mathrm{HCV}$, hepatitis $\mathrm{C}$ virus; ALT, alanine transaminase; $\mathrm{CD}$, cluster of differentiation; Ig, immunoglobulin.

$\mathrm{CD} 27+\operatorname{IgM}+\mathrm{B}$ cells may be associated with autoreactivity and increased susceptibility to autoimmune diseases in patients with $\mathrm{CHC}$.

Alterations in B cell differentiation and activation are frequently noted in pathological conditions (4-6). On this basis, the current study evaluated the differentiation status of IgM+B cell subsets in patients with $\mathrm{CHC}$. Based on the immature $\mathrm{B}$ cell marker $\mathrm{CD} 10$, it was determined that the percentage of $\mathrm{CD} 27-\mathrm{CD} 10+\operatorname{IgM}+\mathrm{B}$ cells was increased in patients with $\mathrm{CHC}$. Previous results have demonstrated that immature B cells are $\mathrm{CD} 10+\mathrm{CD} 27-\operatorname{IgM}+\mathrm{B}$ cells (27) and the current results are consistent with those from a previous study, which identified that $\mathrm{HCV}$ infection was associated with an increase in immature B cells (8). IgD and CD38 are associated with the development of B cells $(22,23)$. In the present study, it was observed that the frequency of CD27-IgD+B cells in IgM+B cells was increased in patients with $\mathrm{CHC}$ compared with HCs. The increased frequency of this subpopulation in IgM+B cells may be associated with chronic HCV stimulation and immune dysfunction 
mediated by CD27-IgD-IgM+B cells. CD38 is a multifunctional ectoenzyme, which participates in lymphocyte activation and terminal differentiation (28). The increased percentage of CD27-CD38+IgM+B cells and CD27+CD38+IgM+B cells imply that chronic $\mathrm{HCV}$ infection may induce the activation and terminal differentiation of certain $\operatorname{IgM}+\mathrm{B}$ cell subsets.

Previous studies have demonstrated that $\mathrm{HCV}$ infection induces the activation of naïve and memory $B$ cell subsets $(11,12,29)$. In the current study, the activation of $\mathrm{IgM}+\mathrm{B}$ cell subsets was assessed based on the expression of the activation marker CD21. It was determined that the activation of $\mathrm{CD} 27+\mathrm{IgM}+\mathrm{B}$ cells was increased in patients with $\mathrm{CHC}$. Furthermore, the expression of distinct molecules associated with B cell activation was evaluated in CD27+IgM+B cells. CD86 is a critical co-stimulatory molecule to facilitate the interaction of T cells with B cells (30). CD95 is a death receptor, which initiates extrinsic pathways of apoptosis to remove activated immune cells (31). Although $\mathrm{HCV}$ infection was associated with an increase in the number of activated $\mathrm{CD} 27+\operatorname{IgM}+\mathrm{B}$ cells, these activated $\mathrm{CD} 27+\operatorname{IgM}+\mathrm{B}$ cell subsets were not correlated with CD86 and CD95 expression. This implies that the activation of $\mathrm{CD} 27+\operatorname{IgM}+\mathrm{B}$ cells may not be associated with $\mathrm{T}$ cell stimulation or apoptosis. Further studies are required to determine the underlying mechanisms that result in increased numbers of activated CD27+IgM+B subsets in the peripheral circulation.

In the present study, the association between $\operatorname{IgM}+\mathrm{B}$ cell subsets and clinical parameters was investigated in patients with CHC. Negative correlations were identified between HCV RNA and CD27-IgD+IgM+B, CD27-CD38+IgM+B and $\mathrm{CD} 27+\mathrm{CD} 38+\operatorname{IgM}+\mathrm{B}$ cells. Although the relative expression of CD27-IgD+IgM+B, CD27-CD38+IgM+B and $\mathrm{CD} 27+\mathrm{CD} 38+\mathrm{IgM}+\mathrm{B}$ cells was higher in patients with $\mathrm{CHC}$ compared with $\mathrm{HCs}$, the exact roles of these IgM+B cell subsets remain unknown. It is possible that chronic $\mathrm{HCV}$ antigen stimulation disrupts the immune response by increasing these IgM+B cell subsets, which, in turn, helps to inhibit HCV replication to some extent in pathological conditions. Further studies are required to determine the roles of these $\operatorname{IgM}+\mathrm{B}$ cell subsets in patients with $\mathrm{CHC}$.

In conclusion, the current study identified the phenotypic abnormalities of $\mathrm{CD} 27-\operatorname{Ig} \mathrm{M}+\mathrm{B}$ and $\mathrm{CD} 27+\operatorname{Ig} \mathrm{M}+\mathrm{B}$ cells in patients with $\mathrm{CHC}$ and demonstrated that the frequencies of IgM+B cell subsets were negatively correlated with viral load. The alterations in $\mathrm{IgM}+\mathrm{B}$ cell subset populations may be associated with the disruption of the $\mathrm{B}$ cell immune response and improved understanding of the association between $\mathrm{IgM}+\mathrm{B}$ cells and $\mathrm{HCV}$ infection will be required in order to identify potential targets for HCV treatment. Despite various limitations of the current study, including the relatively small number of patients with $\mathrm{CHC}$ enrolled and a lack of functional analysis of IgM+B cell subsets in the pathogenic process of $\mathrm{HCV}$ infection, the results of the current study lay a foundation for evaluating the roles and associated mechanisms of certain $\mathrm{IgM}+\mathrm{B}$ cell subsets in patients with $\mathrm{HCV}$.

\section{Acknowledgements}

The authors wish to thank all patients with $\mathrm{CHC}$ for providing blood samples. The current study was funded by the National
Science and Technology Major Project for Infectious Diseases Control during the 12th Five-Year Plan Period (grant no. 2012ZX10002003).

\section{References}

1. Manns MP, Buti M, Gane E, Pawlotsky JM, Razavi H, Terrault N and Younossi Z: Hepatitis C virus infection. Nat Rev Dis Primers 3: 17006, 2017.

2. Park SH and Rehermann B: Immune responses to HCV and other hepatitis viruses. Immunity 40: 13-24, 2014.

3. Ferrari SM, Fallahi P, Mancusi C, Colaci M, Manfredi A, Ferri C and Antonelli A: HCV-related autoimmune disorders in $\mathrm{HCV}$ chronic infection. Clin Ter 164: e305-e312, 2013.

4. Moir S and Fauci AS: B cells in HIV infection and disease. Nat Rev Immunol 9: 235-245, 2009.

5. Sang A, Zheng YY and Morel L: Contributions of B cells to lupus pathogenesis. Mol Immunol 62: 329-338, 2014.

6. Perry HM, Bender TP and McNamara CA: B cell subsets in atherosclerosis. Front Immunol 3: 373, 2012.

7. Sugalski JM, Rodriguez B, Moir S and Anthony DD: Peripheral blood B cell subset skewing is associated with altered cell cycling and intrinsic resistance to apoptosis and reflects a state of immune activation in chronic hepatitis $\mathrm{C}$ virus infection. J Immunol 185: 3019-3027, 2010.

8. Holz LE, Yoon JC, Raghuraman S, Moir S, Sneller MC and Rehermann B: B cell homeostasis in chronic hepatitis C virus-related mixed cryoglobulinemia is maintained through naïve B cell apoptosis. Hepatology 56: 1602-1610, 2012.

9. Racanelli V, Frassanito MA, Leone P, Galiano M, De Re V, Silvestris F and Dammacco F: Antibody production and in vitro behavior of CD27-defined B-cell subsets: Persistent hepatitis C virus infection changes the rules. J Virol 80: 3923-3934, 2006.

10. Mizuochi T, Ito M, Saito K, Kasai M, Kunimura T, Morohoshi T, Momose H, Hamaguchi I, Takai K, Iino S, et al: Possible recruitment of peripheral blood CXCR3+ CD27+ CD19+ B cells to the liver of chronic hepatitis $\mathrm{C}$ patients. J Interferon Cytokine Res 30: 243-252, 2010.

11. Rosa D, Saletti G, De Gregorio E, Zorat F, Comar C, D'Oro U, Nuti S, Houghton M, Barnaba V, Pozzato G and Abrignani S: Activation of naïve $\mathrm{B}$ lymphocytes via CD81, a pathogenetic mechanism for hepatitis C virus-associated B lymphocyte disorders. Proc Natl Acad Sci USA 102: 18544-18549, 2005.

12. Oliviero B, Cerino A, Varchetta S, Paudice E, Pai S, Ludovisi S, Zaramella M, Michelone G, Pugnale P, Negro F, et al: Enhanced $\mathrm{B}$-cell differentiation and reduced proliferative capacity in chronic hepatitis $\mathrm{C}$ and chronic hepatitis B virus infections. J Hepatol 55: 53-60, 2011.

13. Oliviero B, Mantovani S, Ludovisi S, Varchetta S, Mele D, Paolucci S, Baldanti F and Mondelli MU: Skewed B cells in chronic hepatitis $\mathrm{C}$ virus infection maintain their ability to respond to virus-induced activation. J Viral Hepat 22: 391-398, 2015.

14. Della Valle L, Dohmen SE, Verhagen OJ, Berkowska MA, Vidarsson G and Ellen van der Schoot C: The majority of human memory B cells recognizing RhD and tetanus resides in IgM+ B cells. J Immunol 193: 1071-1079, 2014.

15. D'Orsogna LJ, Krueger RG, McKinnon EJ and French MA: Circulating memory B-cell subpopulations are affected differently by HIV infection and antiretroviral therapy. AIDS 21: 1747-1752, 2007.

16. Carsetti R, Rosado MM, Donnanno S, Guazzi V, Soresina A, Meini A, Plebani A, Aiuti F and Quinti I: The loss of IgM memory B cells correlates with clinical disease in common variable immunodeficiency. J Allergy Clin Immunol 115: 412-417, 2005.

17. Roughan JE, Reardon KM, Cogburn KE, Quendler H, Pockros PJ and Law M: Chronic hepatitis C virus infection breaks tolerance and drives polyclonal expansion of autoreactive B cells. Clin Vaccine Immunol 19: 1027-1037, 2012.

18. Rao H, Wei L, Lopez-Talavera JC, Shang J, Chen H, Li J, Xie Q, Gao Z, Wang L, Wei J, et al: Distribution and clinical correlates of viral and host genotypes in Chinese patients with chronic hepatitis C virus infection. J Gastroenterol Hepatol 29: 545-553, 2014.

19. Guo Z, Zhang H, Rao H, Jiang D, Cong X, Feng B, Wang J, Wei L and Chen H: DCs pulsed with novel HLA-A2-restricted CTL epitopes against hepatitis $\mathrm{C}$ virus induced a broadly reactive anti-HCV-specific T lymphocyte response. PLoS One 7: e38390, 2012. 
20. Hardy RR: B-1 B cell development. J Immunol 177: 2749-2754, 2006.

21. Curry MP, Golden-Mason L, Nolan N, Parfrey NA, Hegarty JE and O'Farrelly C: Expansion of peripheral blood CD5+ B cells is associated with mild disease in chronic hepatitis $\mathrm{C}$ virus infection. J Hepatol 32: 121-125, 2000.

22. Perez-Andres M, Paiva B, Nieto WG, Caraux A, Schmitz A, AlmeidaJ, VogtRFJr,MartiGE,Rawstron AC,VanZelm MC, etal: Human peripheral blood B-cell compartments: A crossroad in B-cell traffic. Cytometry B Clin Cytom 78 (Suppl 1): S47-S60, 2010

23. Bemark M, Holmqvist J, Abrahamsson $\mathrm{J}$ and Mellgren $\mathrm{K}$ : Translational Mini-Review Series on B cell subsets in disease. Reconstitution after haematopoietic stem cell transplantationrevelation of $\mathrm{B}$ cell developmental pathways and lineage phenotypes. Clin Exp Immunol 167: 15-25, 2012.

24. Ma L, Qin J, Ji H, Zhao P and Jiang Y: Tfh and plasma cells are correlated with hypergammaglobulinaemia in patients with autoimmune hepatitis. Liver Int 34: 405-415, 2014.

25. Wang J, Shan Y, Jiang Z, Feng J, Li C, Ma L and Jiang Y: High frequencies of activated $\mathrm{B}$ cells and $\mathrm{T}$ follicular helper cells are correlated with disease activity in patients with new-onset rheumatoid arthrits. Clin Exp Immunol 174: 212-220, 2013.
26. Youinou $\mathrm{P}$ and Renaudineau Y: CD5 expression in B cells from patients with systemic lupus erythematosus. Crit Rev Immunol 31: 31-42, 2011.

27. Dörner T, Giesecke C and Lipsky PE: Mechanisms of B cell autoimmunity in SLE. Arthritis Res Ther 13: 243, 2011.

28. Deterre P, Berthelier V, Bauvois B, Dalloul A, Schuber F and Lund F: CD38 in T- and B-cell functions. Chem Immunol 75: $146-168,2000$

29. Kong FY, Feng B, Zhang HH, Rao HY, Wang JH, Cong $X$ and Wei L: CD4+CXCR5+ T cells activate CD27+IgG+ B cells via IL-21 in patients with hepatitis C virus infection. Hepatobiliary Pancreat Dis Int 15: 55-64, 2016.

30. Lim TS, Goh JK, Mortellaro A, Lim CT, Hämmerling GJ and Ricciardi-Castagnoli P: CD80 and CD86 differentially regulate mechanical interactions of T-cells with antigen-presenting dendritic cells and B-cells. PLoS One 7: e45185, 2012.

31. Strasser A, Jost PJ and Nagata S: The many roles of FAS receptor signaling in the immune system. Immunity 30: 180-192, 2009. 